\title{
Effect of different dates of sowing on yield attributes, yield and quality of Barley (Hordeum vulgare L.) cultivars
}

\author{
Ankur Chaudhary*, Meena Sewhag, V.S. Hooda, Bhagat Singh and Parveen Kumar \\ Department of Agronomy, CCS Haryana Agricultural University, Hisar-125004 (Haryana), INDIA \\ *Corresponding author. E-mail: ankurchaudhary292@gmail.com
}

Received: March 8, 2016; Revised received: November 2, 2016; Accepted: January 12, 2017

\begin{abstract}
A study was conducted during rabi 2013-14 at Barley Research Area of CCS Haryana Agricultural University, Hisar with the objective to study the effect of different date of sowing on growth, yield and quality characters of barley cultivars. The experiment was laid out in a split plot design with five date of sowing $\left(30^{\text {th }}\right.$ October, $10^{\text {th }}$, $20^{\text {th }}, 30^{\text {th }}$ November and $10^{\text {th }}$ December) in main plots and four cultivars (BH 902, RD 2552, DWRUB 52 and RD 2668) kept in sub plots replicated thrice. Crop sown on $30^{\text {th }}$ October produced significantly higher values of growth parameters, yield attributes (115 productive tillers per meter row length, no. of grains per spike- 37 and test weight -46.90 ) and yield (grain yield- $4733 \mathrm{~kg} \mathrm{ha}^{-1}$ and straw yield- $8368 \mathrm{~kg} \mathrm{ha}^{-1}$ ). But it was statistically at par with $10^{\text {th }}$ November sowing date. Grain protein content, hectoliter weight and bold grains percentage decreased significantly with delay in sowing while malt content percentage was recorded significantly higher $(89.53 \%)$ in $10^{\text {th }}$ December date of sowing. Among the cultivars DWRUB 52 produced significantly higher grain yield (4516 kg ha-1) and quality attributes like malt content $(86.25 \%)$ than other cultivars.
\end{abstract}

Keywords: Barley, Cultivars, Quality, Sowing time, Yield attributes

\section{INTRODUCTION}

Barley (Hordeum vulgare L.) is the world's fourth most important cereal crop after wheat, rice and maize with a share of seven percent of the global cereals production and 15 percent of coarse grains consumption. In world, barley has 49.2 million hectares area and 139.7 million tonnes production in the year 201415 (Anonymous 2014-15), while in India barley is grown on 0.75 million hectares area with production of 1.92 million tonnes and productivity of $2540 \mathrm{Kg} / \mathrm{ha}$ in the year 2013-14 (Anonymous, 2014). Barley is believed to be originated in Abyssinia and South East Asia. It is a hardy crop and can be successfully grown in adverse climatic conditions of drought, salinity and alkalinity. Both two-row and six-row cultivars are used for malting. Six-rowed cultivars are ideal for beer, and two-rowed are suitable for pure malts. It is preferred over other cereals for malting purpose because its glumes and hulls are firmly cemented to the kernel and remains attached to the grain after threshing and also its husk protects the coleoptile during germination (Singh et al., 2012; Kumar et al., 2014b). Barley is an economically important cereal crop used for producing malt, brewing industries, human food and animal feed used for broilers. To make barley as better crop for changing climate with low inputs, incorporation of genetic resistance to various biotic and abiotic stresses and development of suitable crop production technologies has become the major priority. These efforts have led to the development of a range of new cultivars for different purposes, production conditions and production technologies. Matching the phenology to the prevailing weather conditions is most important factor to maximize the yield of barley. Very early planting may expose the crop to higher temperature at tillering stage while late planting may results in low biomass production and poor grain development due to higher temperature conditions at the time of maturity (Ram et al., 2010; Nass et al., 1975). Keeping this in view the present study was carried out to study phenological and morphological response of barley cultivars to different date of sowing.

\section{MATERIALS AND METHODS}

A field experiment was conducted at Research Area of Wheat and Barley Section, Chaudhary Charan Singh Haryana Agricultural University, Hisar, Haryana (India) during rabi season, 2013-14 on sandy loam soils. The experiment was laid out in a split plot design with five date of sowing $\left(30^{\text {th }}\right.$ October, $10^{\text {th }}, 20^{\text {th }}, 30^{\text {th }}$ November and $10^{\text {th }}$ December) in main plots and four cultivars (BH 902, RD 2552, DWRUB 52 and RD 2668) kept in sub plots replicated thrice. The crop was sown with common row spacing of $22 \mathrm{~cm}$ as per the dates of sowing manually with the help of hand plough by pora method. The soil of the experimental site was deep sandy loam having $7.8 \mathrm{pH}, 0.24 \mathrm{dS} / \mathrm{m}$ EC and low in organic carbon $(0.43 \%)$, low in available $\mathrm{N}$ 
status $\left(138 \mathrm{~kg} \mathrm{ha}^{-1}\right)$, low in available $\mathrm{P}_{2} \mathrm{O}_{5}\left(17 \mathrm{~kg} \mathrm{ha}^{-1}\right)$ and high in available $\mathrm{K}_{2} \mathrm{O}\left(375 \mathrm{~kg} \mathrm{ha}^{-1}\right)$. Yield attributes (effective tillers per meter row length, number of grains per spike and test weight) were recorded at harvest. Harvest index (HI) expressed in percentage as the ratio of grain yield to biological yield, while, the attraction index was calculated by dividing grain yield with straw yield. Hectoliter weight measured with hectoliter weight equipment uses $100 \mathrm{ml}$ volume of grain and gives the value in Kilograms hectoliter- ${ }^{1}$. Bold and thin grain was determined by using sortimate, hundred gram of barley grains sample were taken and they were allowed to pass through the three different sieves of size 2.8, 2.5 and $2.2 \mathrm{~mm}$. Bold grains remain above the sieve size of $2.5 \mathrm{~mm}$ and thin grains passed through it, then percentage of bold and thin grains was calculated. Protein content was analyzed using automatic whole grain analyzer infratech-1241. Malting process of barley grains were carried out as per the procedure suggested by Singh and Sosulski (1985). Available Nitrogen in soil was determined according to alkaline permanganate method by Subbiah and Asija (1956), available P by Olsen's method (Jackson, 1973) and available K in soil was extracted by neutral ammonium acetate and estimated by flame photometer (Piper, 1966).

\section{RESULTS AND DISCUSSION}

Yield attributes and yield -The yield attributing characters of barley viz. Productive tillers per meter row length, spike length, number of grains per spike, test weight recorded under different treatments (Table 1) revealed that $30^{\text {th }}$ October sowing recorded significantly higher number of productive tillers, no. of grains per spike, spike length, test weight which was at par with $10^{\text {th }}$ November sowing, whereas, lowest number of productive tillers, number of grains per spike, spike length and test weight were recorded in $10^{\text {th }}$ December sowing. Alam et al., 2007 also reported that highest number of fertile tillers per plant, number of spikelets per spike and test weight was recorded on $17^{\text {th }}$ November sown crops and decrease with delay in sowing. The reason for this reduction is that presence of high temperature during crop growth period which hasten spike development from floral initiation to anthesis, and also have been found to reduce the number of spikelets formed per spike (Dawson and Wardlaw, 1989).

Maximum number of productive tillers was recorded in cultivar DWRUB 52 and least number of productive tillers was obtained by the cultivar RD 2552. However, the differences between no. of productive tillers in cultivar BH 902 and RD 2552 were not significant. Cultivar DWRUB 52 produced longer spikes than other cultivars. Lowest spike length was obtained in cultivar RD 2552. Barley cultivars RD 2552 produced significantly more number of grains per spike than cultivar BH 902, DWRUB 52 and RD 2668. Barley cultivar DWRUB 52 produced significantly higher test weight than other cultivars (BH 902, RD 2552 and RD 2668). Lowest test weight was obtained in cultivar RD 2552.

Maximum grain, straw and biological yield was recorded in $30^{\text {th }}$ October sowing, which was at par with $10^{\text {th }}$ November sowing (Table 1 ). $20^{\text {th }}$ November, $30^{\text {th }}$ November and $10^{\text {th }}$ December sowing reduced grain yield by $7.58 \%, 13.24 \%$ and $18.65 \%$ respectively as compared to $30^{\text {th }}$ October sowing. The reason being that in $30^{\text {th }}$ October and $10^{\text {th }}$ November sowing favourable conditions prevailed at tillering and grain filling stage. Lowest grain yield, straw yield and biological yield was obtained in $10^{\text {th }}$ December sown barley. This difference in grain yield was attributed to significant reduction of ears $\mathrm{m}^{-2}$, number of grains/ear and 1000-

Table 1. Effect of different date of sowing on yield attributes and yield of barley cultivars.

\begin{tabular}{|c|c|c|c|c|c|c|c|c|c|}
\hline Treatments & $\begin{array}{l}\text { No. of effec- } \\
\text { tive tillers } \\
\text { per plant }\end{array}$ & $\begin{array}{l}\text { Spike } \\
\text { length } \\
\text { (cm) }\end{array}$ & $\begin{array}{l}\text { No. of } \\
\text { grains } \\
\text { per spike }\end{array}$ & $\begin{array}{l}\text { Test } \\
\text { weight } \\
\text { (g) }\end{array}$ & $\begin{array}{l}\text { Grain } \\
\text { yield } \\
\text { (Kg/ha) }\end{array}$ & $\begin{array}{l}\text { Straw } \\
\text { yield } \\
\text { (Kg/ha) }\end{array}$ & $\begin{array}{l}\text { Biologi- } \\
\text { cal yield } \\
(\mathrm{Kg} / \mathrm{ha})\end{array}$ & $\begin{array}{l}\text { Harvest } \\
\text { Index } \\
(\%)\end{array}$ & $\begin{array}{l}\text { Attraction } \\
\text { Index (\%) }\end{array}$ \\
\hline \multicolumn{10}{|l|}{ Date of sowing } \\
\hline $30^{\text {th }}$ October & 115.29 & 7.3 & 37.40 & 46.90 & 4733 & 8368 & 13101 & 36.2 & 57.31 \\
\hline $10^{\text {th }}$ November & 112.25 & 7.0 & 36.95 & 45.96 & 4572 & 8098 & 12670 & 36.3 & 57.25 \\
\hline $20^{\text {th }}$ November & 109.04 & 6.8 & 35.43 & 45.23 & 4374 & 7645 & 12020 & 36.3 & 58.20 \\
\hline $30^{\text {th }}$ November & 102.02 & 6.8 & 34.12 & 43.22 & 4106 & 7419 & 11525 & 35.8 & 56.27 \\
\hline $10^{\text {th }}$ December & 94.72 & 5.4 & 32.83 & 42.50 & 3850 & 6435 & 10285 & 37.3 & 58.01 \\
\hline $\mathrm{SEm} \pm$ & 1.48 & 0.1 & 0.38 & 0.38 & 70.7 & 139.2 & 181.3 & 0.35 & 2.28 \\
\hline $\mathrm{CD}$ at $5 \%$ & 4.92 & 0.4 & 1.28 & 1.26 & 234.1 & 461.0 & 600.5 & NS & NS \\
\hline \multicolumn{10}{|l|}{ Cultivars } \\
\hline BH 902 & 94.06 & 6.6 & 42.04 & 42.28 & 4388 & 8081 & 12469 & 35.3 & 54.80 \\
\hline RD 2552 & 92.63 & 6.0 & 45.29 & 41.09 & 4163 & 8013 & 12176 & 34.4 & 52.50 \\
\hline RD 2668 & 115.66 & 6.9 & 25.67 & 46.09 & 4241 & 7136 & 11377 & 37.2 & 58.97 \\
\hline DWRUB 52 & 124.30 & 7.1 & 28.38 & 49.59 & 4516 & 7143 & 11658 & 38.7 & 63.61 \\
\hline $\mathrm{SEm} \pm$ & 1.66 & 0.1 & 0.38 & 0.32 & 74.6 & 144.3 & 185.5 & 0.41 & 1.36 \\
\hline $\mathrm{CD}$ at $5 \%$ & 4.81 & 0.4 & 1.10 & 0.93 & 216.4 & 418.8 & 538.5 & 1.22 & 3.95 \\
\hline
\end{tabular}


Table 2. Effect of date of sowing on grain quality of different barley cultivars.

\begin{tabular}{|c|c|c|c|c|c|}
\hline \multirow{3}{*}{ Treatments } & Thin & Bold & Hectoliter & Protein & Malt \\
\hline & grain & grain & weight & content & content \\
\hline & $(\%)$ & $(\%)$ & $(\mathrm{Kg} / \mathrm{hl})$ & $(\%)$ & $(\%)$ \\
\hline \multicolumn{6}{|l|}{ Date of sowing } \\
\hline $30^{\text {th }}$ October & 3.2 & 85.3 & 60.5 & 12.06 & 84.27 \\
\hline $10^{\text {th }}$ November & 2.7 & 81.4 & 60.1 & 11.79 & 84.45 \\
\hline $20^{\text {th }}$ November & 5.1 & 79.1 & 59.1 & 11.79 & 84.09 \\
\hline $30^{\text {th }}$ November & 5.9 & 74.0 & 59.3 & 11.61 & 86.26 \\
\hline $10^{\text {th }}$ December & 8.9 & 59.5 & 56.3 & 8.91 & 89.53 \\
\hline $\mathrm{SEm} \pm$ & 0.8 & 2.4 & 0.4 & 0.27 & 0.6 \\
\hline $\mathrm{CD}$ at $5 \%$ & 2.8 & 7.8 & 1.2 & 0.94 & 2.0 \\
\hline \multicolumn{6}{|l|}{ Cultivars } \\
\hline BH 902 & 4.8 & 81.4 & 56.6 & 10.98 & 85.33 \\
\hline RD 2552 & 7.6 & 72.6 & 56.6 & 11.61 & 85.91 \\
\hline RD 2668 & 5.1 & 68.6 & 60.3 & 10.89 & 85.38 \\
\hline DWRUB 52 & 3.1 & 80.9 & 62.7 & 11.43 & 86.25 \\
\hline $\mathrm{SEm} \pm$ & 0.8 & 2.2 & 0.3 & 0.18 & 0.2 \\
\hline $\mathrm{CD}$ at $5 \%$ & 2.5 & 6.4 & 1.0 & 0.57 & NS \\
\hline
\end{tabular}

grain weight. The yield reduction with delay in sowing is due to shorter growing period in vegetative phase and steep rise in temperature at the grain filling stage (Nass et al., 1975 and Ram et al., 2010).

Cultivar DWRUB 52 produced significantly higher grain yield than other cultivars. Lowest grain yield was obtained in cultivar RD 2552. Barley cultivar BH 902, recorded significantly higher straw yield which was at par with RD 2552 as compared to other cultivars. Lowest straw yield and biological yield was obtained by the cultivar RD 2668 and DWRUB 52. Cultivars BH 902 produced maximum biological yield, which was significantly higher than cultivar DWRUB 52, RD 2552 and RD 2668. Harvest and attraction index of barley cultivars does not get influenced with different date of sowing. Among different barley cultivars, DWRUB 52 recorded significantly higher value of harvest and attraction index as compared to other cultivars. The lowest harvest index was recorded in $\mathrm{RD}$ 2552.

Quality analysis- Grain protein content and hectoliter weight decreased significantly with delay in sowing (Table 2). Barley sown on $10^{\text {th }}$ December recorded lowest protein content and hectoliter weight. (Singh et al., 2013) also observed higher protein content in $20^{\text {th }}$ October sowing $(11.2 \%)$ as compared to $10^{\text {th }}$ November sowing $(10.3 \%)$. Malt content percentage was recorded highest in $10^{\text {th }}$ December sowing as compared to October and November sowing. Lower malt content in early sowing was mainly due to higher protein content in the grains of the early sown crop. Malt content percentage shows negative relationship with protein content. Higher malt content percentage and lower protein content in grain of barley cultivar due to delay in sowing (Sarkar et al., 2008; Singh et al., 2013 and Kumar et al., 2014a). Bold grain percentage decreased significantly with delay in sowing while, reverse trend were observed in thin grain percentage, being highest in case of $10^{\text {th }}$ December sown barley. The reason for this was the presence of high temperature during grain filling stage (Nass et al., 1975). Among different barley cultivars, RD 2552 and DWRUB 52 showed superiority in protein content as compared to other two cultivars (BH 902 and $\mathrm{RD}$ 2668). Cultivar DWRUB 52 recorded significantly higher hectoliter weight of barley as compared to other three cultivars (BH 902, RD2552 and RD 2668). Verma et al. (2008) had shown that hectoliter weight is one of the best correlated parameter for malt quality and reported that the cultivars DWRUB 52 and RD 2668 were specifically released for malt purpose, as the hectolitre weight was higher in these two varieties as compared to non-malt purpose varieties. No significant difference was observed due to cultivars on malt content of barley. In the present investigation, highest bold grain percentage was obtained in cultivars DWRUB 52 and BH 902, while cultivars RD 2668 and RD 2552 had lower values. Thin grain percentage was recorded highest in cultivar RD 2552 and lowest in cultivar DWRUB 52. Kumar et al. (2014a) reported highest mean bold grain in DWRUB 52 and BH 902, while lower value in case of varieties RD 2668 and K 551. Thin grain percentage was lowest in DWRUB 52 and highest in case of K 551 .

\section{Conclusion}

From the finding of research conducted it can be concluded that high temperature adversely effect the barley crop by reducing total crop yield. So, selecting an optimum time of planting is a non cash input which if selected properly can help in the overcoming the yield losses oocuring due to high temperature stress. If we consider malt content of barley then late sowing of barley is the best option hance, the sowing time of barley is selected as per its usage, if it has to be used for grain purpose then one should go for optimum date of 
sowing (i.e., in between $30^{\text {th }}$ October to $10^{\text {th }}$ November) and if it is used for brewing purpose then late sowing is recommended.

Among the various barley cultivars, DWRUB 52 should be the first choice followed by BH 902 in terms of yield as well as quality.

\section{REFERENCES}

Alam, M.Z., Haider, S.A. and Paul, N.K. (2007). Yield and yield components of Barley (Hordeum vulgare) in relation to sowing times. J. Bio-Sci., 15: 139-145

Anonymous (2013-2014). Depatment of Agriculture and Cooperation, Ministry of Agriculture , Govt. of India, Krishi Bhavan New Delhi. http;//agricoop.nic.in / Annual report, 2013-2014.

Anonymous, (2014-2015). World barley acreage and production from 2008/2009 to 2014/2015 http;/l www.statista.com/statistics.

Dawson, I. A. and Wardlaw, I. F. (1989). The tolerance of wheat to high temperatures during reproductive growth. III. booting to anthesis. Aust. J. Agril. Res., 40:965-980

Jackson, M.L. (1973). Soil chemical analysis. Prentince Hall of India Pvt. Ltd. New Delhi, pp. 468.

Kumar, D., Narwal, S., Verma, R.P.S., Kumar, V., Kharub, A.S. and Sharma, I. (2014a). Performance of barley varieties for malting quality parameters in north western plains of India. Journal of Wheat Research, 62(2):132-137

Kumar, V., Verma, R.P.S., Kumar, D., Kharub, A.S. and Sharma, I. (2014b). Association of malting quality atriibutes under timely and late sown conditions in barley (Hordeum vulgare L.) Journal of Wheat Research, 6(2): 167-170.

Nass, H.G., Johnston, H.W., Macleod, J.A., and Sterling, D.E. (1975). Effect of sowing date, seed treatment and foliar sprays on yield and other agronomic characters of wheat, oats and barley. Canadian J. Plant Sci., 55: 41147

Piper, C.S. (1966). Soil and Plant analysis. Hans Publishers, Bombay.

Ram, H., Singh, B. and Sharma, A. (2010). Effect of time of sowing on the field performance of Barley (Hordeum vulgare) in PUNJAB. J. Res. Punjab agric. Univ., 47 (3\&4) 132-135

Sarkar, B., Verma, R.P.S. and Mishra, B. (2008). Association of important malting traits in barley (Hordeum vulgare) Indian Journal of Agricultural Sciences, 78: 853-857

Singh, J., Mahal, S.S. and Manhas, S.S. (2012). Effect of sowing methods, nitrogen levels and irrigation scheduling on yield and quality of malt barley (Hordeum vulgare L.). Indian Journal of Agronomy, 57(3):259-264

Singh, T. and Sorsulski, F.W. (1985). Malting of hullers barley (Hordeum vulgar ) cultivars. J. Food Sci.,50:342.

Singh, J., Singh, A. and Mahal, S.S. (2013). Productivity and quality of malt Barley (Hordeum vulgare) as affected by sowing date, rate and stage of nitrogen application. Ind. J. Agron., 58(1):72-80

Subbiah, B.C. and Asija, G.L. (1956). A rapid procedure for the estimation of available nitrogen in soils. Current Sci., 25: 259-260

Verma, R.P.S., Sarkar, B., Gupta, R. and Verma, A. (2008). Breeding barley for malting quality improvement in India. Cereal Research Communication, 36:135-145 